\title{
Does The Internet Financial Reporting Reflect The Sustainability Reporting Higher Education
}

\author{
Erna Sulistyowati ${ }^{1}$, Sjarief Hidajat ${ }^{2}$, Muslimin $^{3}$, Agus Masruhin ${ }^{4}$, Sri Trisnaningsih ${ }^{5}$ \\ \{1ernas.ak@upnjatim.ac.id, ${ }^{2}$ syariefh.ak@upnjatim.ac.id, ${ }^{3}$ muslimin.ak@upnjatim.ac.id, , \\ 4agusmasruhin.upnjatim@gmail.com, ${ }^{5}$ trisna.ak@upnjatim.ac.id\} \\ Universitas Pembangunan Nasional "Veteran" East Java, Indonesia
}

\begin{abstract}
This study aims to analyze whether the contents of the Internet Financial Reporting reflect the sustainability of higher education reporting in Indonesia. This research is categorized as explanatory research, using Content Analysis, for the Internet Financial Reporting and Sustainability Reporting index. The population in this study were 9 of the best universities in Indonesia in 2019/2020 who entered QS World University Rangkings in Indonesia. From the research results, it is obtained that Internet Financial reporting does not reflect Sustainability reporting in tertiary institutions. The limitation of this study is that only colleges that fall into the QS World University Ranking category are expected to be extended to other tertiary institutions, as well as weight calculations for Internet Financial Reporting and Sustainability Reporting. It is hoped that further research will broaden the scope of both state and private tertiary institutions as a whole with various approaches to various types of tertiary institutions and review the weights used in Internet Financial reporting and Sustainability Reporting.
\end{abstract}

Keywords: Higher Education, Internet Financial Reporting, Sustainability Reporting, website

\section{Introduction}

The Industrial Revolution 4.0 has now touched all components of society, especially those related to the use of information that has crossed national borders and scientific boundaries. Likewise with the area of Higher Education is also inseparable from technology that greatly helps all academic activities, which previously conducted traditional learning and is currently developing into a cyber campus that uses internet technology (Forland, Sourin and Sourina 2006). The existence of Higher Education as a cyber campus, makes all matters related to information in the tertiary institution must be disclosed to the public, not least with Higher Education Financial Reporting. Pursuant to RI Law No.12 of 2012 which states tertiary institutions are public bodies that manage tertiary education and refers to Government Regulation No.4 of 2014 concerning higher education accountability, that tertiary institutions as public bodies are obliged to publish annual report information to the public every year. Information released by tertiary institutions will show performance and quality, both from the financial side and from the other side. Submission of information on an ongoing basis so that the public knows more, accepts more students and can survive (Ulum 2010). Like business organizations, 
universities also have the same role as a business organization, also experiencing competition with other universities.

Likewise, reporting using internet technology has provided a new way to communicate company performance (Poon, $\mathrm{Li}$ and $\mathrm{Yu}, 2003$ ). Previous researchers (Poon, $\mathrm{Li}$ and $\mathrm{Yu}$, 2003; Almilia, 2008; Almilia, 2009; Gorgan and Gorgan 2010) used Internet Financial Reporting on companies listed on the Stock Exchange in Hong Kong, Indonesia and Romania. As well as other researchers (Almilia, 2008; Almilia, 2009; Farneti and Guthrie, 2008; Kolk 2008) examined the disclosure of sustainability reporting on companies listed on the Indonesia Stock Exchange, the public sector in Australia, and Fortune Global. Disclosure by previous researchers conducted simultaneously between internet financial reporting and sustainability reporting. Whereas in this study wanted to reveal "whether the Internet Financial Reporting reflects the sustainability of higher education Reporting in Indonesia".

\section{Literature Review}

\section{Legitimacy Theory}

It is an understanding of the implications of social contracts between social institutions and society (Chan et al., 2014). To achieve all institutional objectives, the theory is needed (Erdanu, 2010). Legitimacy Theory suggests all institutions to ensure that all activities and performance of the institution can be accepted by the public. Every institution that can be accepted by the public, then they must submit their annual report that will reflect environmental responsibility. If the company is able to meet all the expectations of society to the company, then the company's position will be strong (legitimate) in the public. This can provide various kinds of benefits for the company. Public does not reject the existence of the company and its operations, because the public feels that the existence of the company benefits the citizen.

\section{Internet Financial Reporting}

Internet financial reporting is a method of distributing financial statements by utilizing the internet or the company's official website as a medium (Poon et al., 2003; Lai et al., 2010). As the opinion (Ettredge et al., 2001; Marston, 2003; Lai et al., 2010) that the internet has become the choice of entrepreneurs in European countries, America and Australia as an alternative tool for their company's financial reporting media.

Poon, $\mathrm{Li}$ and $\mathrm{Yu}$ (2003) try to understand IFR in 100 companies listed on the Hong Kong stock exchange. The results of the study by Poon, Li and $\mathrm{Yu}$ (2003) showed that $87 \%$ implemented IFR. Almilia (2008); Almilia (2009) revealed IFR on 104 company websites listed on the stock exchange in Indonesia. Almilia (2008) results that most of the increase in the IFR index is influenced by the size and profitability factors. Almilia (2009) measures financial information on the Jakarta stock exchange. The results of Almilia's (2009) research stated that not yet fully disclosing company information is done using internet technology. Gorgan and Gorgan (2010) made observations on IFR shifts using XBRL. The results of Gorgan and Gorgan (2010) show that the development of XBRL usage is rather slow than originally estimated. 


\section{Sustainability Reporting}

Tarigan and Semuel (2014) state that sustainability reports contain reports that are not only information on financial performance, but also on non-financial information. among others ; information on social activities and environmental activities that can make a company grow sustainably (sustainable performance). The implementation of sustainability reports in Indonesian tertiary institutions is supported by current government regulations, such as the Higher Education (Undang-undang RI, no. 12 tahun 2012).

Almilia (2008) states that Sutainability Reporting is an effort to minimize negative aspects and optimize positive aspects of company activities in maintaining a positive relationship between stakeholders towards sustainable company development. According to Gazdar (2007) provides an overview of why Sustainability Reporting reports are important, namely increasing the value of the company, meeting stakeholder requests in terms of getting information, reports that can be continuously used by companies for decision making, company performance information will greatly help investors.

\section{Global Reporting Initiative (GRI)}

GRI (2000); GRI (2013); GRI (2015) states that "the practice of measurement, disclosure and accountability efforts of organizational performance in achieving sustainable development goals to stakeholders both internal and external". Almilia (2008) provides evidence that size, profitability, leverage, ownership affect sustainability reporting. Almilia (2009) states that disclosure utilization has not been carried out optimally by companies. Farneti and Guthrie (2008) revealed that all organizations still use the triple bottom line and balanced scorecard in revealing company sustainability and begin to move towards the use of the Global Reporting Initiative.

\section{Higher Education}

According to Law No.12 of 2012, what is meant by higher education is the level of education after secondary education includes diploma, undergraduate, master's, specialist and doctoral education programs organized by universities. Higher education is also a university level consisting of a number of faculties organized by academic and / or professional education in a number of specific disciplines.

\section{Research Methods}

This study aims to analyze whether the reports are ongoing on the performance of internal and external sides (Shareholder and Stakeholder). This type of research can be categorized as explanatory research, using Content Analysis which is a type of research that better describes the condition of an object in more depth and informative or a phenomenon that utilizes text documents (Eriyanto, 2011).

The population in this study is tertiary institutions in Indonesia.

a. Higher Education, based on RI Law No.12 of 2012, article 78 on Accountability of highereducation must be published to the public. 
b. Included in the criteria of the Best University in Indonesia 2019/2020 QS version (QS World University Ranking)

So the sample used in this study is 9 universities in Indonesia, namely: University Indonesia, Gajah Mada University, Bandung Institute of Technology, Bogor Institute of Agriculture, Airlangga University, Binus University, Diponegoro University, and Sepuluh November Institute of Technology.

This research uses: 1) Secondary data, in the form of financial information and non-financial information listed on the website, 2) Using Content Analysis to conclude the calculation results:

a. Internet Financial Reporting, in the form of 4 points, each of which is weighted by $40 \%$ for Content, $20 \%$ on time, $20 \%$ on technology, and $20 \%$ on User Support,

b. Sustainability Reporting, in the form of 20 index items, with a weight $=$ Number of Sustainability disclosures / $20 \times 100$.

The discussion in this study is the Internet Financial Reporting and Sustainability Reporting at universities in Indonesia. Where is the Internet Financial Reporting disclosure index developed by Cheng et al. (2000), Almilia (2008) are as follows:

a. Content, including the balance sheet, income statement, cash flow, changes in financial position and the sustainability report of the relevant tertiary institution,

b. Timeliness, when a college website can present timely information, the higher its index value,

c. Technology Utilization, this component is related to the use of technology that cannot be provided by print media and the use of multimedia technology media,

d. User Support, the index of higher education websites is higher if optimally all facilities on the website such as: media search and navigation / search and navigation tools.

Whereas Sustainability Reporting, also uses the sustainability reporting index from GRI-4 (2013), in the form of: Sustainability reporting information on the university website, Frequently asked questions about sustainability reporting information on the university website, Contact person indicated on the university website, Sustainability information reporting on the college website is displayed in the form of inviting visitors, Information on sustainability reporting on the college website is displayed in visual form, information on sustainability reporting on the website of the college is displayed in the form of vision and mission, Information on sustainability reporting on the college website uses at least 2 languages, Information Sustainability reporting on the website of the tertiary institution is displayed in the form of information on recent activities. Sustainability reporting information on the website of the tertiary institution displays the manager of the tertiary institution, Infor the sustainability reporting on the university website is displayed in the form of information about the operational areas of the college, Sustainability reporting information on the university website is displayed in the form of the latest information about social, environmental and economic activities, Sustainability reporting information on the university website is displayed in the form of how the university handles social, environmental and economic issues, information on sustainability reporting on the university website that is displayed on how to handle social and environmental activities, Information on sustainability reporting on the university website is displayed in the form of an audit report on sustainability reporting that is reported, information on sustainability reporting on the university website is displayed in the form of employment information, sustainability reporting information on the university's website is displayed in the form of negative information, information 
Sustainability reporting on the website of the university is displayed in the form of geography, Information on sustainability reporting on the website of the university is displayed in the form of information about donations received, Information on sustainability reporting on the website of the university is displayed in the form of a code of ethics, Information on sustainability reporting on the website of the college is displayed in the form of comparison of current reports with previous years.

In this study the data analysis technique used is descriptive statistics. Descriptive statistics are statistics used to describe or describe the data that has been collected as it is without the intention to make conclusions that apply to the public or generalizations (Sugiyono, 2006). The data used are secondary data both qualitative and quantitative. Then the analysis technique used is document analysis. The stages of this analysis are: 1) Entering the website of the Indonesian tertiary institution by observing the ease of access, ease of use, convenience of surfing the website, 2) Observing the information displayed on the Indonesian tertiary website, collecting and tabulating information and reviewing the information presented , 3) Interpret the information displayed by linking it to content or content that focuses on the transparency of financial information.

\section{Results and Analysis}

Based on observations from July to August 2019 on the website of universities related to Internet Financial Reporting, it was found that $84 \%$ of tertiary institutions had optimally utilized the existence of the Internet as a means of information disclosure.

Table 1. Financial reporting through the website

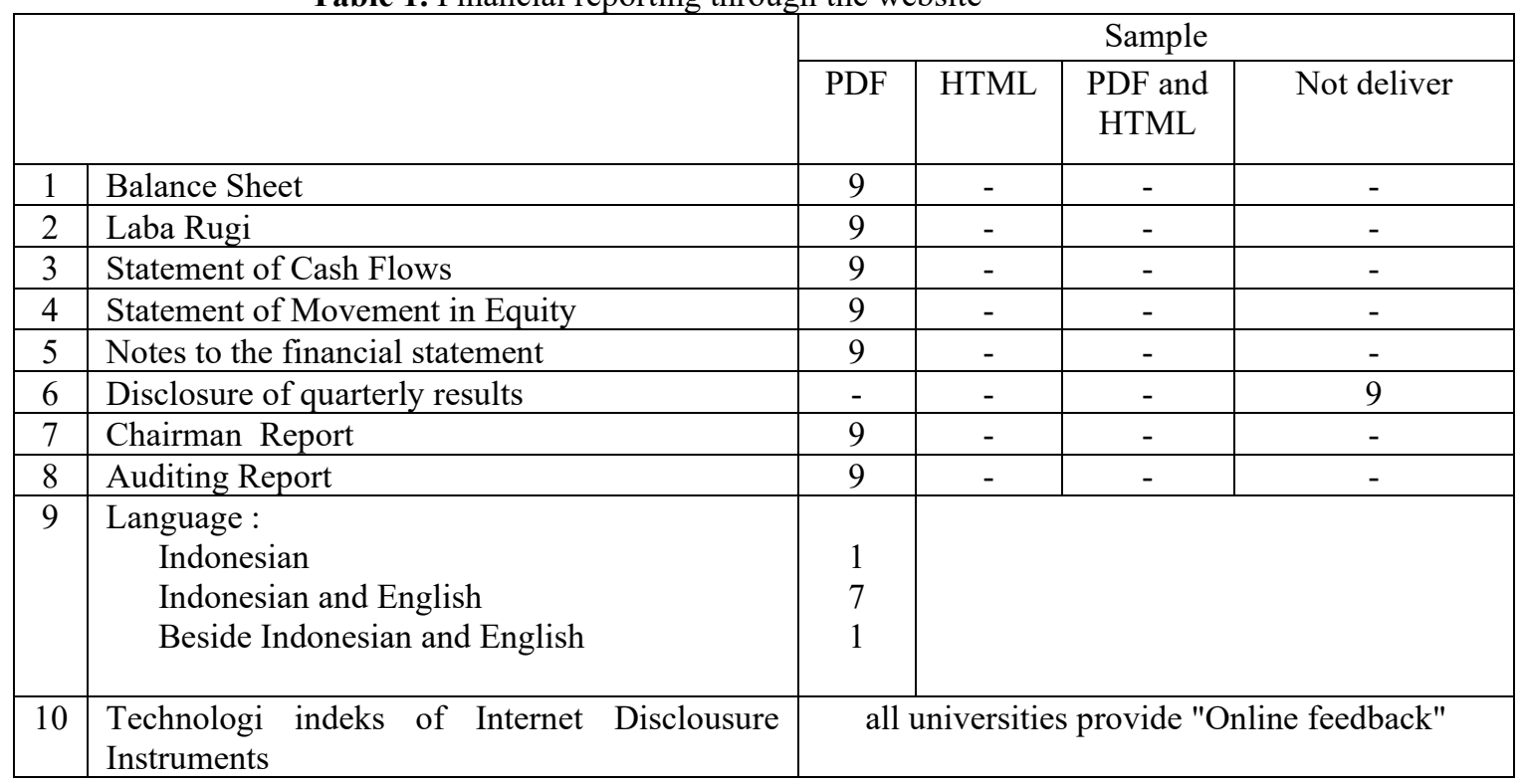

Based on table 1, all universities have utilized internet technology. The number of tertiary institutions observed in this study is 9 tertiary institutions, and 9 of these tertiary institutions 
display complete financial statements on the tertiary's website. All of these universities did not display Disclosure of quarterly results on the financial statements. Out of the 9 tertiary institutions that display their financial statements, all tertiary institutions display in PDF format. and all universities display complete in the form of a Balance Sheet, Profit and Loss, Cash Flow, Equity Change Report and notes to the financial statements. Then none of the tertiary institutions reported quarterly information on financial reports, only reporting annually. Based on the use of language, 1 tertiary institution displays only in Indonesian, 7 tertiary institutions use Indonesian and English, and only 1 tertiary institution displays language use in more than 2 languages. The addressing of tertiary institutions is done by all tertiary institutions.

Based on timeliness, none of the tertiary institutions presents timely information. Meanwhile, based on the use of technology, there are all universities that provide 'Online Feedback' and based on user support, most universities try to display all support for users in order to optimally utilize the facilities on the college website. Although for universities that display financial statements, it turns out to go to the content in question cannot only be 1 or 2 clicks away, too many clicks must be exceeded.

From 9 tertiary institutions, all of them delivered information on the sustainability of tertiary institutions on the main menu of the website, question and answer facilities, contact persons, photographs, vision and mission of the tertiary institution. And only 6 universities provide guarantees for ongoing reports made with other parties that audit and report on the university's website. None of the tertiary institutions provides information related to the absorption of the number of students, negative things related to sustainability information, geography, code of ethics and information on the sustainability of tertiary institutions compared to the previous year. Only at the point of contribution to the community that is displayed continuously on 9 college websites, in the form of community service.

Most of the tertiary institutions in the 2019/2020 best version of the QS World University Rangkings version, do not display financial information on the main website of the tertiary institution as a means of communication as well as a means of sustaining higher education, although it has been stated by the government through the RI Law No.12 years 2012 that universities as Educational Institutions are required to release information to the public. The tertiary institution only displays nonfinancial information on the main tertiary website.

Even though the universities that are in the category 9 of the Best Universities in Indonesia in 2019/2020 version of the QS World University Rangkings, but not all of them display financial information through the main website of the tertiary institution, this does not affect prospective students to choose the said tertiary institution. Also, it has no effect on the Sustainability Reporting of higher education, this is evidenced by the website of the university which continuously informs Sustainability reporting.

So the hypothesis which states Internet Financial Reporting reflects the Sustainability Reporting of the university is not proven.

\section{Conclusion}

From the results of the study, it was stated that the Internet Financial Reporting did not reflect Sustainability Reporting in tertiary institutions. Whereas the routine delivery of Internet Financial Reporting every year should have a positive impact on the sustainability of the tertiary institution in the future. As well as providing an insight into Internet Financial 
Reporting as part of sustainability reporting that will reflect the performance of tertiary institutions, both state and private tertiary institutions, especially in Indonesia.

The limitations of this study were only carried out in the 9 best universities in Indonesia in 2019/2020 version of the QS World University Rangkings, as well as the weight calculation of the Internet Financial Reporting and Sustainability Reporting. It is hoped that further research will broaden the scope of both state and private tertiary institutions as a whole with a variety of approaches to various types of tertiary institutions and review the weights used in Internet Financial reporting and Sustainability Reporting.

\section{References}

1. Almilia, L 2008, 'faktor-faktor yang mempengaruhi pengungkapan sukarela "Internet Financial and Sustainability Reporting”, JAAI,Volume 12 No.2, December 2008. Pp.117-131.

2. Almilia, L 2009,'Determining factors of Internet Financial Reporting in Indonesia', Accounting \& Taxation, Vol. 1, No. 1, pp. 87-99, 2009, 2009 - papers.ssrn.com

3. Chan, M. C., Watson, J., Woodliff, D. (2014). Corporate Governance Quality and CSR Disclosure. Journal of Business ethics, 125 (1), 59-73, doi: $\mathrm{http} / / \mathrm{dx}$.doi.org/10.1007/s10551-013-1887-8

4. Cheng, A. Lawrence, S ; Coy, D. (2000).'Measuring the Quality of Corporate Financial Websites: A New Zealand Study. Paper presented at the 12th Asian-Pasific Confrence on International Accounting Issues - Beijing.

5. Etredge, M.; Richardson, V, J.; Scholz, S. (2001). "The Presentation of Financial Information at Corporate Web Sites", International Journal of Accounting Information System, 2 149-168.

6. Farneti, F and Guthrie, J 2008,'Sustainability Reporting by Australian Public Sector Organisations: Why they Report', Accounting Forum,

7. Forland, E, Sourin, A and Sourina, O 2006,'Cybercampuses: design issues and future directions', Visual Computing, pp.1-14.

8. Gazdar, Kaevan (2007). Reporting Nonfinancials, Jhon Wiley and Sons, Ltd

9. Global Reporting Initiative, 2013, G4 Guidilines.

10. Gorgan,C and Gorgan, V 2010,'An Evolutionary Approach of Internet Financial Reporting', Anale. Seria Stiinte Economice.

11. Kolk, A 2008,'Sustainability, Accountability and Corporate Governance: Exploring Multinational's Reporting Practices', Business Strategy and the Environment.

12. Lai, Syou-Ching., Lin, Cecilia., Li, Hung-Chih., Wu, Frederick H., 2010. "An Empirical Study of the Impact of Internet Financial reporting on Stock Prices", The International Journal of Digital Accounting Research, Vol.10, pp. 1-26, ISSN : $1577-$ 8517

13. Marston, Claire (2003)."Financial Reporting on the internet by leading Japanese Companies", Corporate Communication: An International Journal, Vol.8 Iss 1, pp.2324

14. Peraturan Pemerintah No.12 Tahun 2012,'Pedoman dan Penyelenggaraan Pendidikan'.

15. Poon, Li and Yu, 2003,'Internet Financial Reporting', Information Control Journal, Volume 1, 2003 
16. QS World University Rangkings, Ranking Web of World Universities, di search 16 Juli 2019 ,

17. Sugiyono, 2006,'Metode Penelitian Bisnis', Alfabeta, CV, Bandung.

18. Ulum, Ihyaul 2010,'Mengintroduksi Laporan Tahunan Perguruan Tinggi', di search 27 Juli 2019,

$<$ http://www.Ihyaul.staff.umm.ac.id/2010/12/mengintroduksi-laporan-tahunan> 